\title{
DIRECT AND INDIRECT EFFECTS OF OPERANT RESOURCES ON CO-CREATION EXPERIENCE: EMPIRICAL EVIDENCE FROM AIRBNB CONSUMERS
}

\author{
Revi HASTARI ${ }^{1}$, Zehan ADELA ${ }^{2}$, Hanesman ALKHAIR ${ }^{3}$, \\ Alexander Joseph Ibnu WIBOWO ${ }^{*}$ \\ 1, 2, 3, 4 School of Business and Economics, Universitas Prasetiya Mulya, \\ Jl. BSD Raya Barat I, BSD City, Serpong, Tangerang 15339, Indonesia
}

Received 20 October 2018; accepted 18 February 2019

\begin{abstract}
This study aims to empirically analyze the direct and indirect effects of operant resources on co-creation experience of Airbnb consumers. Specifically, this study examines operant resources' impact on perceived benefits, trust, and co-creation experience. In addition, this study also investigates the effect of perceived benefits, and trust on co-creation experience. We managed to collect a sample of 201 respondents obtained through online surveys. Respondents were consumers who have used Airbnb service offerings. Data were gathered using a questionnaire developed on the basis of a literature review. A convenience sampling was adopted in inviting consumers to participate in this study. The hypotheses were analyzed using simple and multiple linear regression analysis. The results show that operant resources are proven to influence perceived benefits, and trust of consumers. Likewise, perceived benefits, trust, and operant resources have been shown to influence the co-creation experience. The novelty and the most important contribution of this study are that it has succeeded in proving empirically the existence of the Service-Dominant Logic (S-D Logic) perspective.
\end{abstract}

Keywords: service-dominant logic, operant resources, co-creation experience, value co-creation, tourism.

JEL Classification: D83, L83, L86, M31, Z32, Z33.

\section{Introduction}

Nowadays, we are able to observe the people's changing lifestyle which becomes increasingly mobile. Specifically, this can be seen from the changes in the people's way of life and behavior in spending time through various activities and hobbies, as well as in expressing opinions about something (Kotler 2002). Generally, these lifestyle changes cannot be separated from its connection with the development of internet technology. As is known, the existence and important role of the internet is increasingly felt to support humans in solving various complex problems. In business, internet development has changed the way managers and owners do business. Currently, online business models have developed very fast throughout the world. This business model is considered to be able to simplify, accelerate, and improve the efficiency of business processes, and is able to expand market reach.
Airbnb is one company that has successfully developed a business model. As is well known, Airbnb is a company from the United States that offers convenience for residential owners (hosts) who want to rent their homes to other people who want to rent a room, house, or apartment, within a certain period. Airbnb offers rental rates that are cheaper than rental rates in conventional hotels. The choice of occupancy is relatively diverse because the residential property is owned by a residential owner, not Airbnb. Consumers (tourists) can experience a unique holiday experience through various activities with local residents. Consumers can also choose activities that suit their hobbies or interests.

Interactions that occur between consumers and residential owners, and even with local residents can create a unique shared experience for each consumer. It means that consumers can actually engage or participate in the co-creation activities (process) of value and unique

*Corresponding author. E-mail: ibnu.wibowo@pmbs.ac.id 
experiences together with producers (residential owner and Airbnb) and local residents. This is supported by Saarijärvi et al. (2013) who state that the main key in marketing and business management services is the value creation. In addition, an understanding of value creation, which previously focused on the company, is now increasingly emphasizing on the role of consumers in the process of value creation (Prahalad and Ramaswamy 2003, Vargo and Lusch 2004). This shift of view is one of the ideas in the S-D Logic perspective. This new perspective also reveals the exchange of intangible resources between consumers and producers, such as the exchange of knowledge, skills, abilities, and expertise. The above intangible resources are often referred to as operant resources.

In summary, we want to analyze the co-creation experience from the consumer's side. Furthermore, we attempt to empirically examine the relationship between co-creation experience and the four antecedents, namely operant resources, perceived benefits, and trust. This research actually continues and deepens the previous studies conducted by Alves et al. (2016), and Alves and Mainardes (2017). In contrast, our research wants to investigate more deeply in the context of Airbnb consumers based on the S-D Logic perspective.

\section{Literature review}

\subsection{Operant resources}

Operant resources are specialized knowledge and skills, which will later become a competitive advantage of the company (Madhavaram and Hunt 2008). A person's competence in the form of a set of knowledge and skills can be applied through an action for the benefit of their own or another organization (Vargo 2008; Vargo et al. 2008). In line with the perspective of S-D Logic, Flint et al. (2014) argue that operant resources are intangible and dynamic. For example, in the process of making pizza, operant resources are people who use their knowledge and ability to make pizza. In addition, operant resources are used to act on operand resources and other operant resources (Vargo and Lusch 2004). A study by Alves et al. (2016) found evidence that operant resources, such as customer education, customer expertise, and social capital, influence co-creation with companies.

Today the development of internet technology has changed the way consumers get information about hotels, flights, or tourist destinations (Grissemann and Stokburger-Sauer 2012). Consumers (tourists) must face a new and different transaction process than it used to be so that they need new knowledge to be able to process the transaction. Li and Petrick (2008) stated that knowledge is a source of competitive advantage in the tourism industry. Therefore, integrating the knowledge and skills possessed by producers and consumers will increasingly enable the creation of value-in-context, namely the pleasure, satisfaction, and happiness of consumers and producers.

\subsection{Co-creation experience}

According to Prahalad and Ramaswamy (2004), highquality interactions that allow consumers to gain unique co-creation experiences with companies are the keys to find new resources for competitive advantage. Therefore, the value must be made jointly by companies and consumers. Prahalad and Ramaswamy (2004) describe cocreation as shared value creation by producers and consumers. When a company only focuses on consumers and regards consumers as "kings" that are always true, they are not considered as co-creation. On the other hand, Agrawal and Rahman (2015) describe eleven role groups that consumers can have in the process of creating value creation. If consumers have one of these roles, then they have already done value creation processes or activities with the company. These roles include co-producers, codistributors, co-promoters, co-manufacturers, co-consumers, the customer as experience creators, customer an innovators, co-ideators, co-evaluators, co-designers, and customers as co-testers.

Co-creation helps consumers in building a shared service experience according to the customer's situation. If the company provides good services or spoils consumers with luxurious services, then it also does not include co-creation. Co-creation is interpreting a problem and solving the problem together between the company and the consumer (Prahalad and Ramaswamy 2004). In addition, co-creation creates an experiential environment where consumers engage actively in dialogue and together with companies in building experiences tailored to the consumer desires. In this process, the product may be the same, but each consumer can have a different experience. Co-creation offers a variety of experiences for each customer and not only offers a variety of products (Prahalad and Ramaswamy 2004). The co-creation experience is centered on consumers who form value and interact with companies to form shared values (Prebensen et al. 2013). Creating a unique experience requires the participation of consumers and connections that connect consumers with that experience (Pine and Gilmore 1998, Shaw et al. 2011). Operant resources, such as customer education, customer expertise, and social capital, have been shown to influence co-creation with the company (Alves et al. 2016, Alves and Mainardes 2017). In addition, perceived benefits and trust have also been shown to influence the co-creation behavior (Alves and Mainardes 2017). In tourism, creating unique and memorable experiences for consumers is very important so that companies are able to compete in this industry (Grissemann and Stokburger-Sauer 2012).

\subsection{Perceived benefits}

Perceived benefits are defined as benefits perceived by consumers and are antecedents of consumer participation in value creation in a virtual community (Nambisan and Baron 2009). Similarly, Roberts et al. (2014) stated that perceived benefits can encourage participation in 
co-creation activities. The greater benefits the customers perceive in their relationship with the company, the greater their level of participation in creative-based activities with the company (Alves and Mainardes 2017). According to Hsu et al. (2007), the formation of positive behavior between individuals can be due to knowledge sharing activities. The perceived benefits occur when individuals believe that they can improve relationships by offering knowledge they have. The perceived benefits also proved to influence co-creation behavior (Alves and Mainardes 2017). In tourism, benefits can be derived from how people work together to collaborate and use the resources they have in the field of tourism (Zhang et al. 2009, Yilmaz and Bititci 2006, Wynne et al. 2001) and later they will obtain benefits that create more effective value (Vargo et al. 2008).

\subsection{Trust}

Morgan and Hunt (1994) have emphasized the important role of trust in the company. Trust is one of the core variables to show loyalty (Sirdeshmukh et al. 2002). The greater a person's trust in the company, the greater their chances of wanting to maintain relationships and engage in business in the future. In addition, trust also ensures consumers get value from future business transactions with the same supplier (Aurier and N'Goala 2010). Trust can reduce risk in exchange, provide continuity in relationships, and maintain loyalty. Consumers are also more likely to give advice and make recommendations to their friends and relatives about the companies they trust (Flint et al. 2011). Trust has also been shown to influence the co-creation behavior (Alves and Mainardes 2017) and intention to travel (Abubakar and Ilkan 2016). In addition, identity and strategy build stakeholder trust (Melewar et al. 2017). Yang et al. (2018) in their study of Airbnb services have shown that the cognitive trustidentity attachment building mechanism is more effective than affective trust-bond attachment depending on the emotional distance between the users and hosts. Trust was the foundation on which the sharing economy was built. Without trust, people would never invite strangers to live in their house or ride in their car (Leung et al. 2019).

\section{Conceptual framework and hypotheses}

\subsection{Relationships between operant resources and perceived benefits}

Vargo and Lusch (2004) revealed that in the perspective of the S-D Logic, service is defined as the application of the competencies (knowledge and skills) possessed to provide benefits for themselves and others. According to Vargo and Lusch (2017), the main role of operant resources (knowledge and skills) is when these resources can act on other resources and form a benefit. Nowicki et al. (2018) assert that competency is a fundamental resource of corporate strategy formation where the incorporation of knowledge, skills, and capabilities can be used to create a value proposition. Based on the description above, we propose the first hypothesis as follows:

H1: Operant resources owned by consumers affect the perceived benefits of Airbnb consumers.

\subsection{Relationships between operant resources and trust}

Kalaignanam and Varadarajan (2006) convey about customer engagement in value chain management. Similarly, customers can provide input, such as money, time, effort, and skills, to participate in the prosumption process (Xie et al. 2008). Customer expertise can influence motivation, desires, and the amount of customer participation in service delivery through collaboration (Lusch et al. 2007). Besides, relationship portfolio management capability can prove fruitful for relationship marketing strategy. Like companies, consumers also have relational competencies that are useful in the establishment, development, and maintenance of successful relational exchanges. Furthermore, the composite operant resources have a positive influence on the firm in terms of relational outcomes (Madhavaram and Hunt 2008). According to Madhavaram et al. (2014), competency plays a role in the creation of relationship marketing strategies. Companies with higher competencies are better able to create customer relationship marketing strategies. Therefore, operant resources play an important role in building relationship quality, such as trust. Based on the explanation above, we propose the second hypothesis as follows:

H2: Operant resources owned by consumers affect consumer trust in Airbnb.

\subsection{The relationship between perceived benefits and co-creation experience}

According to Ennew and Binks (1999), consumers will participate if they benefit from relationships with the company. The greater the benefits perceived by consumers in their relationships with companies, the greater their level of participation in co-creation-based activities with the company (Alves and Mainardes 2017). Nambisan and Baron (2009) find that perceived consumer benefits are antecedents of consumer participation in value co-creation in virtual communities. Similarly, Roberts et al. (2014), propose that perceived benefits can act as motivations to participate in co-creation activities. Verleye (2015) concludes that the expected co-creation benefits determine the importance of the level of customer role readiness, technologization, and connectivity for the co-creation experience. The expected co-creation benefits that customers actually get in return for co-creation determine their overall co-creation experience. Based on the explanation above, we propose the third hypothesis as follows:

H3: Perceived benefits affect co-creation experience of Airbnb consumers. 


\subsection{The relationship between trust and co-creation experience}

The concept of trust and value co-creation is closely related because the purpose of interaction and business relationships is value creation (Vargo 2009). Trust provides assurance regarding the consistency and competency of the company's performance and ensures that consumers continue to get value from future business transactions with the same company (Aurier and N'Goala 2010).

Trust can be one of the factors influencing the potential for value creation (Nahapiet and Ghoshal 1988). When a relationship has a high level of trust, the parties involved will be more willing to engage in a social exchange. According to Alves and Mainardes (2017), trust has been shown to influence the co-creation behavior. Similarly, consumers will show a higher level of co-creation activity if: (i) the consumer has trust in the company; (ii) these consumers feel that they can benefit from exchanging experiences with other consumers; and (iii) these consumers feel empowered with tools and resources that enhance their perception of self-efficacy. Based on the description above, we propose the fourth hypothesis as follows:

H4: Consumer trust in the company influences co-creation experience of Airbnb consumers.

\subsection{The relationship between operant resources and co-creation experience}

According to Vargo et al. (2008), companies will use their understanding and capabilities in carrying out production activities and product branding. In addition, consumers also apply their own understanding and abilities in their daily use. The resources that consumers have are the most important foundation for the company in doing co-creation. Therefore, consumers are one of the most valuable strengths that a company has (Lusch and Vargo 2006).

Similarly, Auh et al. (2007) argued that the ability of consumers is not only limited to their participation in service production, but it also involves a higher level of expertise to be able to participate in service production. Study Alves et al. (2016) asserted that operant resources, such as customer education, customer expertise, and social capital, have been shown to influence co-creation with the company. Based on the above explanation, we propose the fifth hypothesis as follows:

H5: Operant resources owned by consumers affect Airbnb's consumer co-creation experience.

Overall, the relationship between variables as outlined in the conceptual framework above is summarized in the conceptual model below (see Figure 1).

\section{Research methods}

\subsection{Research type}

This research is a descriptive study in which data collection is done using a survey questionnaire. Descriptive method is used to examine a group of people, objects,

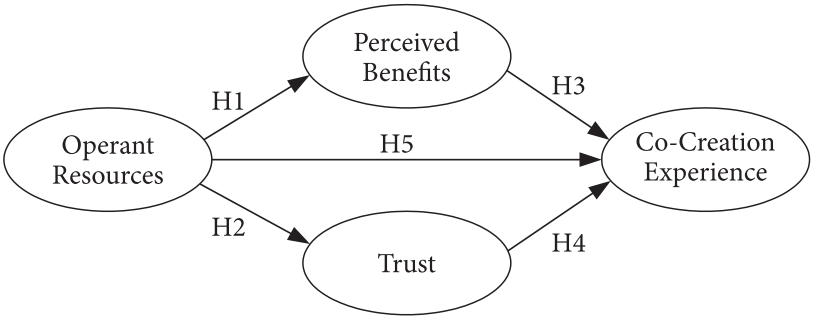

Figure 1. Conceptual model

conditions, and events that occur in the present (Malhotra 2010). The purpose of this descriptive research is to obtain a description of the facts, properties, and relationships between phenomena that are being systematically investigated. Specifically, we will analyze the relationship between a number of variables, such as operant resources, perceived benefits, trust, and co-creation experience.

\subsection{Population and sample}

The population is an aggregate of all elements that share some common characteristics for the purpose of marketing research problems (Malhotra 2015). The population of this study is all consumers or Airbnb service users who live in Jakarta, Bogor, Depok, Tangerang and Bekasi (Indonesia). The sample is a subgroup of the population chosen to participate in the study (Malhotra 2015). The sample of this research is Airbnb consumers who have made a transaction at least once, both women and men, aged between 18 and 38 years.

\subsection{Sampling technique}

We used convenience sampling to gather data because there is no reliable sampling frame with which to conduct a random sampling. Convenience sampling is a sampling technique that is carried out by taking the easiest elements of the population. In this technique, researchers have the freedom to determine members of the population that are considered easy to be chosen as respondents (Malhotra 2010). A number of studies have identified a preference among authors for non-probability sampling methods (Wiese and Jordaan 2012, Poon and Rowley 2007, Albaum and Peterson 1984). Non-probability sampling design, such as convenience and judgmental, was extensively used, which is surprising considering the limitations inherent in such research. The adoption of probability samples was reported less frequently but experienced increasing use over time (Leonidou et al. 2010).

\subsection{Operationalization of variables}

We tested the validity and reliability of the instrument through a pre-test involving thirty respondents (Malhotra 2010). We hope that the instrument applied to the actual sample will be valid and reliable. A number of indicators were corrected after obtaining input from the results 
of this pre-test. We use a number of indicators for each construct based on previous studies. The construct of co-creation experience is measured by four indicators from Yi and Gong (2013). For the construct of perceived benefits, we use four indicators made by Chan et al. (2010) and Nambisan and Baron (2009). Furthermore, three indicators for the construct of trust are obtained from Kinard and Capella (2006). Finally, the construct of operant resources is measured by four indicators from Ojasalo (2001) and Bell and Eisingerich (2007).

All of the above indicators are translated into Indonesian and adapted to the context of Airbnb. Each construct above is measured by a number of indicators or measurement variables using a seven-point Likert Scale from 1 "Strongly disagree" to 7 "strongly agree". Completely, all indicators for each construct are presented in Table 1 below.

\subsection{Validity and reliability test}

According to Malhotra (2015), the validity test aims to examine the extent to which the differences in the observed scale scores reflect the correct differences between objects on measured characteristics rather than systematic or random errors. Validity test results are measured by factor loading scores. An indicator is said to be valid if it has a factor loading value greater than 0.5 (Malhotra 2010). On the other hand, reliability testing refers to an understanding that the instrument used is reliable as a data collection tool and refers to the extent to which the scale produces consistent results if the measurement is repeated (Malhotra 2015). The reliability for each construct was obtained using the Cronbach's Alpha (CA) coefficient. The whole process of analysis to test the validity and reliability of the instruments is done using SPSS.

Acceptable levels of reliability depend on the objectives of the research project (Katerattanakul and Siau 1999). There are researchers who claim that a CA value of 0.7 is considered adequate (Davis 1995). Malhotra (2010) considers the value is reliable if the instruments have a Cronbach's Alpha score greater than 0.6. According to Nunnally (1978), measurements with CA values equal to or greater than 0.70 can be accepted or can be called reliable. However, in a preliminary study, a CA score of 0.5 to 0.6 was considered quite reliable, and a CA score above 0.8 was considered difficult to obtain (Nunnally 1967). On the other hand, Lin (2010) states that the construct is said to be very reliable when the CA value is greater than 0.7 ; quite reliable when the value falls between 0.5 and 0.7 ; and the least reliable when the value is below 0.5 . In fact, Mann and Rawat (2016) argued that a CA score of 0.5 was categorized as fairly reliable. According to them, the indicator can be removed if the CA score is less than 0.5. O'Donovan and McCarthy (2002) caution that the CA score in the initial survey can be satisfactory, but the CA score in the main survey can be unsatisfactory. Similarly, the fewer indicators, the lower the CA score (Frankforter and Guidry 2015, Nunnally 1967).

Table 1. Operationalization of variables

\begin{tabular}{|c|c|c|c|}
\hline Constructs & Indicators & Codes & Sources \\
\hline \multirow{4}{*}{$\begin{array}{l}\text { Co-creation } \\
\text { Experience }\end{array}$} & $\begin{array}{l}\text { During service provision or whenever entering into a contract, I provide } \\
\text { the appropriate and necessary information to ensure good service } \\
\text { provision. }\end{array}$ & CE1 & \multirow{4}{*}{ Yi and Gong (2013) } \\
\hline & $\begin{array}{l}\text { During service provision or whenever entering into a contract with the } \\
\text { company, I have an agreeable attitude towards company members of staff. }\end{array}$ & CE2 & \\
\hline & I give advice about the service to other consumers. & CE3 & \\
\hline & I have a certain tolerance towards possible company service failures. & CE4 & \\
\hline \multirow{4}{*}{$\begin{array}{l}\text { Perceived } \\
\text { Benefits }\end{array}$} & I receive a higher quality service & PB1 & \multirow{4}{*}{$\begin{array}{l}\text { Chan et al. (2010), } \\
\text { Nambisan and Baron } \\
(2009)\end{array}$} \\
\hline & Provides me with solutions to specific product usage-related problems. & PB2 & \\
\hline & $\begin{array}{l}\text { Enhances my knowledge about advances in products, related products, and } \\
\text { technology. }\end{array}$ & PB3 & \\
\hline & Gives me enjoyment from problem-solving, idea generation, etc. & PB4 & \\
\hline \multirow{3}{*}{ Trust } & $\begin{array}{l}\text { I'm confident that the company and its employees will correctly provide the } \\
\text { service. }\end{array}$ & TR1 & \multirow{3}{*}{$\begin{array}{l}\text { Kinard and Capella } \\
(2006)\end{array}$} \\
\hline & I trust the advice provided by this company and its employee. & TR2 & \\
\hline & I believe this company and its employees worry about my needs. & TR3 & \\
\hline \multirow{4}{*}{$\begin{array}{l}\text { Operant } \\
\text { Resources }\end{array}$} & I have a good level of knowledge of service operation. & OR1 & \multirow{4}{*}{$\begin{array}{l}\text { Ojasalo (2001), Bell } \\
\text { and Eisingerich } \\
(2007)\end{array}$} \\
\hline & I understand the benefits of this service. & OR2 & \\
\hline & I understand the limitations of this service. & OR3 & \\
\hline & I feel confident about the means of applying this service. & OR4 & \\
\hline
\end{tabular}


The results of the factor analysis of 30 respondents in the pre-test showed that all indicators or measurement variables were proven valid because they had a factor loading value above 0.5 . That is, all of these indicators have measured the construct that should be measured and can be trusted as a measuring tool. Similarly, all indicators are proven reliable because they have a Cronbach's Alpha value above 0.6 . Based on the results of the validity and reliability tests above, all instruments do not need to be repaired and they can be distributed to the actual respondents.

\section{Data analysis techniques}

\subsection{Descriptive analysis}

In this study, we measured several descriptive statistics, such as frequency, mean, and standard deviation. Some demographic variables were analyzed, such as gender, age, residence, and expenditure. In addition, all variables in the research model were also analyzed using descriptive statistics, such as operant resources, perceived benefits, trust, and co-creation experience.

\subsection{Regression analysis}

We use regression analysis techniques to test the five hypotheses proposed. There are two types of regression analysis, namely simple linear regression and multiple linear regression. Regression analysis is a statistical procedure to analyze the associative relationship between one dependent variable with one or more independent variables (Malhotra 2015). Before conducting a regression analysis, we test the classical assumptions first. The purpose of this test is to ascertain whether a number of criteria have been met before applying regression analysis. There are two classical assumption tests that we do, namely normality test and multicollinearity test. Specifically, the normality test is applied to simple and multiple linear regression models, while the multicollinearity test is applied only to multiple linear regression models.

The normality test is conducted to find out whether the research variables have normal distribution or not. The normality test is done by analyzing the histogram and normal probability plot. The model fulfills the assumption of normality if the histogram shows normal distribution, and the p-plot graph shows the spread points around the diagonal line and follows the direction of a line (Ghozali 2016). On the other hand, a multicollinearity test was conducted to determine whether there was a multicollinearity trend in multiple linear regression models. Symptoms of multicollinearity are indicated by a significant correlation between independent variables. Multicollinearity test is done by looking at tolerance values and Variant Inflation Factor (VIF). If the tolerance score is greater than 0.10 or VIF is less than 10, multicollinearity does not occur between the independent variables (Ghozali 2016). In summary, the mathematical formula for Model 1 and 2 is presented below:

$$
\begin{aligned}
& Y_{1}=a+\beta_{1} X_{1}+e \\
& Y_{2}=a+\beta_{2} X_{2}+e
\end{aligned}
$$

where $Y_{1}$ is perceived benefits; $Y_{2}$ is trust; $X_{1}$ and $X_{2}$ are operant resources; $a$ is constant; $\beta_{i}$ is beta coefficient for $X_{i} ; e$ is erroneous. Next, a mathematical formula for Model 3 is presented below:

$$
Y_{1}=a+\beta_{1} X_{1}+\beta_{2} X_{2}+\beta_{3} X_{3}+e,
$$

where: $Y_{1}$ is co-creation experience; $X_{1}$ is perceived benefits; $X_{2}$ is trust; $X_{3}$ is operant resources; $a$ is constant; $\beta_{i}$ is beta coefficient for $X_{i} ; e$ is erroneous.

Similarly, we calculate the coefficient of determination $\left(\mathrm{R}^{2}\right)$. The coefficient of determination is used to measure the ability of the model to explain the variation of the dependent variable. This value measures how much influence of the independent variable has on the dependent variable. The value of a small determination coefficient means the ability of the independent variable to explain the dependent variable is limited. Conversely, if the coefficient of determination shows a large value, it means that the variable provides sufficient information to predict the dependent variable (Ghozali 2012).

\section{Results}

\subsection{Profile of respondents and descriptive analysis}

We managed to obtain data from 201 respondents. The majority of respondents were Airbnb consumers who were male, over 25 years of age, residing in South Jakarta, with varying personal expenses of up to six million rupiahs per month. In summary, the profile of respondents can be seen in Table 2 .

In general, the average score for the four co-creation experience indicators is greater than five. This shows that consumers have gained co-creation experience with residential owners or Airbnb. Specifically, consumers have been friendly to the residential owner and provided the information needed to get good service during the service or whenever there is contact with Airbnb. Similarly, consumers advise other consumers about Airbnb service and can be tolerant of service failures.

Furthermore, the average value for the four perceived benefit indicators is also greater than five. This shows that consumers have felt the benefits gained from Airbnb service. Consumers feel that they receive better quality service during relationships with Airbnb. In addition, consumers feel that interactions with other Airbnb users are able to increase knowledge about Airbnb and are able to provide solutions to certain problems related to Airbnb usage, and are able to help consumers in problem-solving, idea formation, and others.

The average value for the three indicators of consumer confidence is also greater than five. This shows that consumers have believed that Airbnb and residential owners 
Table 2. The demographic profile of respondents

\begin{tabular}{|c|c|c|}
\hline Description & Frequency & Percentage \\
\hline \multicolumn{3}{|l|}{ Sex: } \\
\hline Female & 114 & 56.7 \\
\hline Male & 87 & 43.3 \\
\hline \multicolumn{3}{|l|}{ Age: } \\
\hline$<25$ years & 168 & 83.6 \\
\hline $26-35$ years & 33 & 16.4 \\
\hline \multicolumn{3}{|l|}{ Residence: } \\
\hline South Jakarta & 63 & 31.5 \\
\hline Tangerang & 44 & 22 \\
\hline West Jakarta & 30 & 15 \\
\hline North Jakarta & 15 & 7.5 \\
\hline Bekasi & 15 & 7.5 \\
\hline East Jakarta & 13 & 6.5 \\
\hline Central Jakarta & 8 & 4 \\
\hline Bogor & 6 & 3 \\
\hline Depok & 6 & 3 \\
\hline \multicolumn{3}{|c|}{ Expenditure (IDR million): } \\
\hline$<1$ & 4 & 2 \\
\hline $1-2$ & 23 & 11.4 \\
\hline $2-3$ & 42 & 20.9 \\
\hline $3-4$ & 49 & 24.4 \\
\hline $4-5$ & 34 & 16.9 \\
\hline $5-6$ & 17 & 8.5 \\
\hline$>6$ & 32 & 15.9 \\
\hline
\end{tabular}

can provide appropriate service. In addition, consumers also trust the advice provided by Airbnb and residential owners, and occupancy owners are considered to care about their needs.

Finally, the mean value of the four operant resources indicators is also greater than five. This indicates that consumers know the benefits to be gained by using Airbnb and feel confident in using Airbnb service. In addition, consumers have a good level of knowledge in operating Airbnb and every limitation found on the service offered by Airbnb. Moreover, the average value and standard deviation of all indicators can be seen in Table 3 .

\subsection{Results of validity and reliability test}

Based on the results of the validity test, we found that all indicators in this study were valid. The factor loading value varies from the lowest of 0.532 (PB1) to the highest of 0.861 (TR2). Likewise, the reliability test results prove that all instruments are reliable, except the co-creation experience which has a Cronbach's Alpha value of less than
Table 3. Results of descriptive statistical analysis, validity test, and reliability test

\begin{tabular}{|c|c|c|c|c|}
\hline Variables & Mean & SD & $\begin{array}{c}\text { Factor } \\
\text { loadings }\end{array}$ & $\begin{array}{c}\text { Cronbach's } \\
\text { alpha }\end{array}$ \\
\hline \multicolumn{3}{|c|}{ Co-creation experience (CE) } & & 0.563 \\
\hline CE1 & 6.16 & 0.654 & 0.785 & \\
\hline CE2 & 6.30 & 0.70 & 0.724 & \\
\hline CE3 & 5.59 & 1.129 & 0.646 & \\
\hline CE4 & 4.93 & 1.280 & 0.580 & \\
\hline \multicolumn{3}{|c|}{ Perceived benefits (PB) } & & 0.748 \\
\hline PB1 & 5.92 & 0.835 & 0.532 & \\
\hline PB2 & 5.58 & 1.051 & 0.817 & \\
\hline PB3 & 5.65 & 1.058 & 0.815 & \\
\hline PB4 & 5.32 & 1.053 & 0.819 & \\
\hline \multicolumn{3}{|l|}{ Trust (TR) } & & 0.782 \\
\hline TR1 & 5.88 & 0.778 & 0.836 & \\
\hline TR2 & 5.76 & 0.802 & 0.861 & \\
\hline TR3 & 5.60 & 0.944 & 0.817 & \\
\hline \multicolumn{3}{|c|}{ Operant resources (OR) } & & 0.774 \\
\hline OR1 & 5.65 & 0.974 & 0.786 & \\
\hline OR2 & 5.88 & 0.752 & 0.827 & \\
\hline OR3 & 5.56 & 1.053 & 0.773 & \\
\hline OR4 & 5.70 & 0.883 & 0.816 & \\
\hline
\end{tabular}

0.6 , which is 0.563 . Read more, the results of the validity and reliability test can be seen in Table 3 .

The results show that all instruments are reliable, including co-creation experience which has the lowest CA score $(0.563)$. This construct can be categorized as quite reliable because it has a CA value between 0.5 and 0.7 (Nunnally 1967, Lin 2010). This is also supported by Mann and Rawat (2016) that a CA score of 0.5 is categorized as fairly reliable. Therefore, we accept or maintain all constructs and indicators, including co-creation experience, and then we carry out variously advanced analyses, such as regression.

\subsection{Results of regression analysis}

The classical assumption test that we use is the normality test and multicollinearity test. The normality test is done by analyzing the histograph and probability plot. Overall, we found that the data had met the assumption of normality. This can be seen from a histogram showing a bell-like shape. In addition, a probability plot also shows a view where the points spread following a diagonal line from the zero points and do not widen too far from the diagonal line. After testing for normality, we conducted a multicollinearity test. The results of the analysis indicate that there are no symptoms of multicollinearity. This can 
be seen from the tolerance value greater than 0.10 . Based on the results of the classical assumption test above, then we conduct a regression analysis to test the hypotheses that we propose.

A simple linear regression analysis was used to test $\mathrm{H}_{1}$, which tested the effect of operant resources on perceived benefits. The result showed that operant resources $(\beta=$ $0.379, \mathrm{p}<0.001$ ) significantly affected perceived benefits. Therefore, $\mathrm{H}_{1}$ was not rejected. The coefficient of determination for $\mathrm{R}^{2}$ value for the predicted variable was 0.139 (above the critical value 0.1 ), which could be considered to indicate a substantial level of explanation (Schroer and Hertel 2009). It means that as much as 13.9 percent of the perceived benefits could be explained using the operant resources, while the rest (86.1 percent) was explained by other variables not examined in this study. Likewise, a simple linear regression analysis was used to test $\mathrm{H}_{2}$, which tested the effect of operant resources on consumer trust. The result showed that operant resources $(\beta=0.530$, $\mathrm{p}<0.001$ ) significantly affected consumer trust. Therefore, $\mathrm{H}_{2}$ was not rejected. The coefficient of determination for $\mathrm{R}^{2}$ value for the predicted variable was 0.277 (above the critical value 0.1 ), which could be considered to indicate a substantial level of explanation (Schroer and Hertel 2009). It means that as much as 27.7 percent of the consumer trust can be explained using the operant resources, while the rest (72.3 percent) was explained by other variables not examined in this study.

Finally, the multiple linear regression analysis was used to test $\mathrm{H}_{3}, \mathrm{H}_{4}$ and $\mathrm{H}_{5}$, which tested the effect of perceived benefits, trust, and operant resources on cocreation experience (Table 4). The result showed that perceived benefits $(\beta=0.341, \mathrm{p}<0.001)$, trust $(\beta=0.247$, $\mathrm{p}<0.001)$, and operant resources $(\beta=0.173, \mathrm{p}<0.05)$ significantly affected co-creation experience. Therefore, $\mathrm{H}_{3}, \mathrm{H}_{4}$ and $\mathrm{H}_{5}$ were not rejected. The coefficient of determination for $\mathrm{R}^{2}$ value for the predicted variable was 0.359 (above the critical value 0.1 ), which could be considered to indicate a substantial level of explanation (Schroer and Hertel 2009). It means that as much as 35.9 percent of the co-creation experience could be explained using the perceived benefits, trust, and operant resources, while the rest (64.1 percent) was explained by other variables not examined in this study.

\section{Discussions}

According to the S-D Logic perspective, consumers play an active role in the value creation process or activity. Likewise, exchanges or transactions are carried out in the form of an exchange of processes or activities (not a unit of output), namely the exchange of knowledge and skills (operant resources), which is also called the service for service exchange. S-D Logic perspective defines service (singular) as an application of competencies, knowledge, and skills to provide benefits to other parties. Goods (unit of output) do not become the basis of exchange, but only become "vehicles" or tools (intermediaries) to deliver service. In the case of Airbnb, the place of residence, rental housing or housing that is rented by consumers is a tool (intermediary) to deliver service to consumers.

S-D Logic lens views consumers, not as targets, but actors who actively integrate their resources to create value together with other actors who receive benefits (the beneficiaries) from service exchanges. So, the value creation process is carried out jointly by all actors involved and beneficiaries of this exchange. In the case of Airbnb, the actors involved and benefited were at least three, namely consumers, Airbnb, and house owners (host). These actors will exchange each operant resources to obtain new operant resources from other actors and also value in context, such as pleasure, satisfaction, happiness, or others, which are unique to each actor.

In the context of Indonesia, Arifina and Ayu (2018) have conducted studies on Airbnb against local hosts in Yogyakarta city. They mention that local hosts consciously and voluntarily advertise vacant rooms in their homes through the Airbnb platform. Local hosts have high confidence in the Airbnb because it has a technology system that can help local hosts to control information about their homes against the desired guest. In addition, the local host considers the house not only a place for cultural and social activities but also used as a place to generate additional income through sharing tourism.

The most important finding of this research is to succeed in providing empirical evidence that supports and strengthens the existence of S-D Logic perspective. As is known, this perspective confirms the important role of consumer resources, especially operant resources, in the value co-creation process. As revealed by Vargo and Lusch

Table 4. Results of regression analysis

\begin{tabular}{|c|l|c|c|c|}
\hline Model & \multicolumn{1}{|c|}{ Relationships } & $\mathrm{b}$ & $t$ & Conclusions \\
\hline 1 & Operant resources $\rightarrow$ Perceived benefits & $0.379^{* * *}$ & 5.778 & Not rejected \\
\hline 2 & Operant resources $\rightarrow$ Trust & $0.530^{\star * *}$ & 8.815 & Not rejected \\
\hline 3 & Perceived benefits $\rightarrow$ Co-creation experience & $0.341^{* * *}$ & 5.351 & Not rejected \\
\hline 3 & Trust $\rightarrow$ Co-creation experience & $0.247^{* * *}$ & 3.521 & Not rejected \\
\hline 3 & Operant resources $\rightarrow$ Co-creation experience & $0.173^{*}$ & 2.535 & Not rejected \\
\hline
\end{tabular}

${ }^{*} \rho<0.05 ;{ }^{* *} \rho<0.01 ;{ }^{* * *} \rho<0.001$ 
(2017), consumers actively integrate their resources in the process of value creation together with producers. So, a consumer also has another network and becomes part of his/her network. These consumers can act as resource integrators, namely integrating various resources they have. In summary, this study has succeeded in proving the existence of the S-D Logic perspective through the finding that operant resources can play a direct and indirect cause in determining the co-creation experience. As is known, this co-creation experience is created during the value co-creation process.

In the context of Airbnb service, this study has succeeded in proving that operant resources influence the benefits perceived by Airbnb consumers. This confirms the importance of consumer knowledge of the benefits that will be obtained if they use Airbnb. Consumers also need the knowledge to use the Airbnb application or site because consumers have to make their own orders. Search engines provided by Airbnb in the applications and sites can help consumers to find places to stay and desired tourist destinations. As is known, destinations that Airbnb customers will visit can be foreign places and far from their homes. Therefore, Airbnb companies need to continue to build interactions with consumers to share knowledge about Airbnb offerings. If consumers have knowledge of Airbnb service, consumers can increasingly feel the benefits of Airbnb offerings, including being willing to provide solutions to certain issues related to Airbnb usage.

Moreover, operant resources are also proven to influence consumer trust. This finding confirms the importance of consumer knowledge about the benefits that will be obtained if they use Airbnb. The majority of Airbnb consumers are young people who can be very knowledgeable. They are connected to each other and are very proactive to share with each other, including sharing knowledge and experience. Similarly, Airbnb needs to establish relationships and dialogue with consumers to share knowledge about Airbnb. If consumers have knowledge of Airbnb, consumer trust in Airbnb will also increase.

This study also succeeded in proving the significant influence of perceived benefits, trust, and operant resources on co-creation experience. Sequentially, the most powerful determinants are perceived benefits, followed by trust and finally operant resources. So, consumers perceive that they get benefits if Airbnb service is able to provide solutions to consumer problems. The benefits perceived by consumers can increase the consumer's co-creation experience.

Consumer trust in the company was also found to significantly influence co-creation experience. This trust arises from the good relationship between Airbnb and consumers. Operant resources owned by consumers have an important role in forming consumer trust in Airbnb. The results of this study confirm that consumer operant resources are the biggest determinant in the formation of consumer trust. Consumer trust can be seen from the ability of Airbnb and residential owners to solve consumer problems. Consumer trust in Airbnb can enhance co-creation experience, such as advising other consumers about
Airbnb and tolerating the possibility of Airbnb service failures. In addition, Airbnb has facilities that can accommodate reviews of customer experience after a vacation.

Likewise, consumers who have more knowledge about benefits and Airbnb service have a greater likelihood of getting a co-creation experience. So, increasing consumer knowledge can improve their co-creation experience. Finally, the findings of this study reaffirm the important role of interactor's interaction during the process of service exchange and value co-creation. The interaction between consumers, local residents, and residential owners, for example, is able to create knowledge exchange and cocreation experience between them. Dialogues between consumers and residential owners can further increase their respective knowledge due to the differences in lifestyle and culture between them. This is what makes every consumer vacation trip succeeds in creating a unique cocreation experience.

\section{Conclusions}

The existence of the internet has changed the way of doing business. Currently, the online business model is very popular because it has the ability to simplify business processes. Business models like this are faster, efficient, and have the ability to expand market reach. Airbnb has become one of the companies that successfully develop this business model. Airbnb offers a co-creation experience that can drive business growth quickly.

S-D Logic has opened a new logic of thinking where consumers have an active role in value creation. The active role is shown by the presence of operant resources, namely knowledge, and skills, owned by consumers and producers. This research is based on S-D Logic's perspective by looking at how the process of co-creation experience can be influenced by factors, such as perceived benefits, trust, and operant resources. In summary, this research has succeeded in proving that operant resources can act as direct and indirect determinants of co-creation experience.

The results showed that all variables were examined, namely perceived benefits, trust, and operant resources, have been shown to significantly influence the co-creation experience. Perceived benefits have the greatest influence on co-creation experience. Besides, operant resources also have a significant effect on perceived benefits and trust. Operant resources also have the greatest influence on trust. Likewise, consumer trust also has a significant impact on co-creation experience.

In summary, the findings of this study have succeeded in providing empirical evidence of the important role of consumers' operant resources as a direct and indirect determinant of consumers' co-creation experience. Companies can utilize consumer resources in the value co-creation process. So, consumers and other stakeholders are active and dynamic operant resources and can contribute to the value co-creation process, such as co-innovation and co-production. 


\section{Limitations}

This study found that indicators to measure the construct of co-creation experience proved to be fairly reliable. This causes the possibility of giving different or inconsistent conclusions if this indicator is used repeatedly. Therefore, further research is expected to be able to design other more reliable indicators to measure this construct.

Likewise, the sample in this study does not represent the population because the data collection used nonprobability sampling technique. A high prevalence of nonprobability samples limits the representativeness and generalisability of authors' research results (Wiese and Jordaan 2012). Such sampling method can be considered as biased sampling in its selection process since it may not be considered a representative sample of the population (Malhotra and Birks 2006). Researchers should work towards more representative sampling methods in their research, especially if they want to demonstrate scientific rigor in their research approaches and statistical techniques (Wiese and Jordaan 2012). The next empirical study can be done by utilizing probability sampling and the model through replication research. Studies in different contexts will further strengthen the empirical model built, and then able to support and further strengthen the existence of the S-D Logic perspective.

\section{References}

Abubakar AM, Ilkan M (2016) Impact of online WOM on destination trust and intention to travel: a medical tourism perspective. Journal of Destination Marketing \& Management 5 (3): 192-201. https://doi.org/10.1016/j.jdmm.2015.12.005

Agrawal AK, Rahman Z (2015) Roles and resource contributions of customers in value co-creation. International Strategic Management Review 3 (1/2): 144-160.

https://doi.org/10.1016/j.ism.2015.03.001

Albaum G, Peterson RA (1984) Empirical research in international marketing: 1976-1982. Journal of International Business Studies 15: 161-173.

https://doi.org/10.1057/palgrave.jibs.8490479

Alves H, Ferreira JJ, Fernandes CI (2016) Customer's operant resources effects on co-creation activities. Journal of Innovation and Knowledge 1 (2): 69-80.

https://doi.org/10.1016/j.jik.2016.03.001

Alves H, Mainardes EW (2017) Self-efficacy, trust, and perceived benefits in the co-creation of value by consumers. International Journal of Retail and Distribution Management 45 (1): 1159-1180.

https://doi.org/10.1108/IJRDM-05-2016-0071

Arifina AS, Ayu AS (2018) Expectancy violation in private space rental experienced by Airbnb localhost. MetaCommunication; Journal of Communication Studies 3 (2): 1-14 https://ppjp.ulm.ac.id/journal/index.php/MC/article/viewFile/5441/4592

Auh S, Bell SJ, McLeod CS, Shih E (2007) Co-production and customer loyalty in financial services. Journal of Retailing 83 (3): 359-370. https://doi.org/10.1016/j.jretai.2007.03.001

Aurier P, N'Goala G (2010) The differing and mediating roles of trust and relationship commitment in service relation- ship maintenance and development. Journal of the Academy of Marketing Science 38 (3): 303-325. https://doi.org/10.1007/s11747-009-0163-Z

Bell SJ, Eisingerich AB (2007) The paradox of customer education: customer expertise and loyalty in the financial services industry. European Journal of Marketing 41 (5/6): 466-486. https://doi.org/10.1108/03090560710737561

Chan KW, Yim KCB, Lam SSK (2010) Is customer participation in value creation a double-edged sword? Evidence from professional financial services across cultures. Journal of Marketing 74 (3): 48-64.

https://doi.org/10.1509/jmkg.74.3.48

Davis D (1995) Business research for decision making (4th ed.). Belmont, CA: Wadsworth.

Ennew CT, Binks MR (1999) Impact of participative service relationships on quality, satisfaction, and retention: an exploratory study. Journal of Business Research 46: 121-132. https://doi.org/10.1016/S0148-2963(98)00016-22

Flint DJ, Blocker CP, Boutin PJ (2011) Customer value anticipation, customer satisfaction, and loyalty: an empirical examination. Journal of Industrial Marketing Management 40: 219-230. https://doi.org/10.1016/j.indmarman.2010.06.034

Flint DJ, Lusch RF, Vargo SL (2014) The supply chain management of shopper marketing as viewed through a service ecosystem lens. Journal of Physical Distribution and Logistics Management 44 (1/2): 23-38.

https://doi.org/10.1108/IJPDLM-12-2012-0350

Frankforter SA, Guidry TL (2015) Who needs ETS? How to create a psychometric assessment test. American Journal of Management 15 (1): 73-80 http://www.na-businesspress. com/AJM/FrankforterSA_Web15_1_.pdf

Ghozali I (2012) Aplikasi analisis multivariate dengan program IBM SPSS 20. Semarang: Universitas Diponegoro.

Ghozali I (2016) Aplikasi analisis multivariate dengan program IBM SPSS 23. Semarang: Universitas Diponegoro.

Grissemann US, Stokburger-Sauer NE (2012) Customer cocreation of travel services: the role of company support and customer satisfaction with the co-creation performance. Journal of Tourism Management 33 (6): 1483-1492. https://doi.org/10.1016/j.tourman.2012.02.002

Hsu MH, Ju TL, Yen CH, Chang CM (2007) Knowledge sharing behavior in virtual communities: the relationship between trust, self-efficacy, and outcome expectations. International Journal of Human-Computer Studies 65 (2): 153-169. https://doi.org/10.1016/j.ijhcs.2006.09.003

Kalaignanam K, Varadarajan R (2006) Customers as co-producers: implications for marketing strategy effectiveness and marketing operations efficiency. In: Lusch RF, Vargo SL (Eds). The service-dominant logic of marketing: dialog, debate, and directions. Armonk, NY: M.E. Sharpe, 166-179.

Katerattanakul P, Siau K (1999) Measuring information quality of websites: development of an instrument. Proceedings of International Conference on Information Systems (ICIS), Paper 25 http://aisel.aisnet.org/icis1999/25

Kinard BR, Capella ML (2006) Relationship marketing: the influence of consumer involvement on perceived service benefits. Journal of Services Marketing 20 (6): 359-368. https://doi.org/10.1108/08876040610691257

Kotler P (2002) Manajemen pemasaran. Edisi Millenium. Jilid 2. Jakarta: PT Prenhallindo. 
Leonidou LC, Barnes BR, Spyropoulou S, Katsikeas CS (2010) Assessing the contribution of leading mainstream marketing journals to the international marketing discipline. International Marketing Review 27 (5): 491-518. https://doi.org/10.1108/02651331011076563

Leung XY, Xue L, Wen H (2019) Framing the sharing economy: toward a sustainable ecosystem. Tourism Management 71: 44-53. https://doi.org/10.1016/j.tourman.2018.09.021

Li X, Petrick JF (2008) Tourism marketing in an era of paradigm shift. Journal of Travel Research 46 (3): 235-244. https://doi.org/10.1177/0047287507303976

Lin LY (2010) The relationship of consumer personality trait, brand personality, and brand loyalty: an empirical study of toys and video games buyers. Journal of Product and Brand Management 19 (1): 4-17.

https://doi.org/10.1108/10610421011018347

Lusch RF, Vargo SL (2006) Service-dominant logic: reactions, reflections, and refinements. Marketing Theory 6 (3): 281 288. https://doi.org/10.1177/1470593106066781

Lusch RF, Vargo SL, O’Brien M (2007) Competing through service: insights from service-dominant logic. Journal of Retailing 83 (1): 5-18.

https://doi.org/10.1016/j.jretai.2006.10.002

Madhavaram S, Granot E, Badrinarayanan V (2014) Relationship marketing strategy: an operant resource perspective. Journal of Business and Industrial Marketing 29 (4): 275283.

https://doi.org/10.1108/JBIM-02-2013-0049

Madhavaram S, Hunt SD (2008) The service-dominant logic and a hierarchy of operant resources: developing masterful operant resources and implications for marketing strategy. Journal of the Academy of Marketing Science 36 (1): 67-82. https://doi.org/10.1007/s11747-007-0063-z

Malhotra NK (2010) Marketing research: An applied orientation $\left(6^{\text {th }}\right.$ ed). New Jersey: Pearson Education.

Malhotra NK (2015) Essentials of marketing research: a handson orientation. New Jersey: Pearson Education.

Malhotra NK, Birks D (2006) Marketing research: an applied approach (3rd ed). Prentice Hall, Upper Saddle River. https://doi.org/10.1108/S1548-6435(2006)2

Mann BJS, Rawat J (2016) The role of consumer personality trait and brand personality trait in creating customer experience. The IUP Journal of Brand Management 13 (3): 23-42

https://ssrn.com/abstract=2966625

Melewar TC, Foroudi P, Gupta S, Kitchen PJ, Foroudi MM (2017) Integrating identity, strategy and communications for trust, loyalty and commitment. European Journal of Marketing 51 (3): 572-604.

https://doi.org/10.1108/EJM-08-2015-0616

Morgan R, Hunt SD (1994) The commitment-trust theory of relationship marketing. Journal of Marketing 58 (3): 20-38. https://doi.org/10.2307/1252308

Nahapiet J, Ghoshal S (1998) Social capital, intellectual capital, and the organizational advantage. Academy of Management Review 23 (2): 242-260. https://doi.org/10.2307/259373

Nambisan S, Baron RA (2009) Virtual customer environments: Testing a model of voluntary participation in value co-creation activities. Journal of Product Innovation Management 26 (4): 388-406.

https://doi.org/10.1111/j.1540-5885.2009.00667.x
Nowicki D, Sauser B, Randall W, Lusch RF (2018) Service-dominant logic and performance-based contracting: a systems thinking perspective. Journal of Service Science 10 (1): 1224. https://doi.org/10.1287/serv.2017.0185

Nunnally JC (1967) Psychometric theory. New York: McGraw Hill, New-York.

Nunnally JC (1978) Psychometric theory (2nd ed). New-York: McGraw-Hill.

O’Donovan P, McCarthy M (2002) Irish consumer preference for organic meat. British Food Journal 104 (3/4/5): 353-370. https://doi.org/10.1108/00070700210425778

Ojasalo J (2001) Customer expertise. Services Marketing Quarterly 22 (2): 1-16. https://doi.org/10.1300/J396v22n02_01

Pine JB, Gilmore JH (1998) Welcome to the experience economy. Harvard Business Review 76 (4): 97-105.

Poon HF, Rowley C (2007) Contemporary research on management and human resources in China: a comparative content analysis of two leading journals. Asia Pacific Business Review 13 (1): 133-153. https://doi.org/10.1080/13602380601016984

Prahalad CK, Ramaswamy V (2003) The new frontier of experience innovation. MIT Sloan Management Review 44 (4): 12-18.

Prahalad CK, Ramaswamy V (2004) Co-creation experiences: the next practice in value creation. Journal of Interactive Marketing 18 (3): 5-14. https://doi.org/10.1002/dir.20015

Prebensen N, Vittersø J, Dahl TI (2013) Value co-creation significance of tourist resources. Journal of Annals of Tourism Research 42: 240-261. https://doi.org/10.1016/j.annals.2013.01.012

Roberts D, Hughes M, Kertbo K (2014) Exploring consumers' motivations to engage in innovation through co-creation activities. European Journal of Marketing 48 (1/2): 147-169. https://doi.org/10.1108/EJM-12-2010-0637

Saarijärvi H, Kannan PK, Kuusela H (2013) Value cocreation: theoretical approaches and practical implications. European Business Review 25 (1): 6-19.

Schroer J, Hertel G (2009) Voluntary engagement in an open web-based encyclopedia: wikipedians and why they do it. Media Psychology 12 (1): 96-120. https://doi.org/10.1080/15213260802669466

Shaw G, Bailey A, Williams AM (2011) Service-dominant logic and its implications for tourism management: the co-production of innovation in the hotel industry. Tourism Management 32 (2): 207-214. https://doi.org/10.1016/j.tourman.2010.05.020

Sirdeshmukh D, Singh J, Sabol B (2002) Consumer trust, value, and loyalty in relational exchanges. Journal of Marketing 66 (1): 15-37. https://doi.org/10.1509/jmkg.66.1.15.18449

Vargo SL (2008) Customer integration and value creation. Paragdimatic traps and perspectives. Journal of Service Research 11 (2): 211-215. https://doi.org/10.1177/1094670508324260

Vargo SL (2009) Toward a transcending conceptualization of relationship: a service-dominant logic perspective. Journal of Business \& Industrial Marketing 24 (5/6): 373-379. https://doi.org/10.1108/08858620910966255

Vargo SL, Lusch RF (2004) Evolving to a new dominant logic for marketing. Journal of Marketing 68 (1): 1-17. https://doi.org/10.1509/jmkg.68.1.1.24036

Vargo SL, Lusch RF (2008) Service-dominant logic: continuing the evolution. Journal of the Academy of Marketing Science 36 (1): 1-10. https://doi.org/10.1007/s11747-007-0069-6 
Vargo SL, Lusch RF (2017) Service-dominant logic 2025. International Journal of Research in Marketing 34 (1): 46-67. https://doi.org/10.1016/j.ijresmar.2016.11.001

Vargo SL, Maglio PP, Akaka MA (2008) On value and value co-creation: a service systems and service logic perspective. European Management Journal 26 (3): 145-152. https://doi.org/10.1016/j.emj.2008.04.003

Verleye K (2015) The co-creation experience from the customer perspective: its measurement and determinants. Journal of Service Management 26 (2): 321-342. https://doi.org/10.1108/JOSM-09-2014-0254

Wiese M, Jordaan Y (2012) A content analysis of the research practices reported in the management journal "Management Dynamics". Management Dynamics 21 (3): 33-47.

Wynne C, Berthon PP, Pitt L, Ewing M, Napoli J (2001) The impact of the Internet on the distribution value chain: the case of the South African tourism industry. International Marketing Review 18 (4): 420-431. https://doi.org/10.1108/EUM0000000005934

Xie C, Bagozzi RP, Troye SV (2008) Trying to prosume: toward a theory of consumers and co-creators of value. Journal of the Academy of Marketing Science 36 (1): 109-122. https://doi.org/10.1007/s11747-007-0060-2
Yang S-B, Lee K, Lee H, Koo C (2018) In airbnb we trust: understanding consumers' trust-attachment building mechanisms in the sharing economy. International Journal of Hospitality Management (November 2018). https://doi.org/10.1016/j.ijhm.2018.10.016

Yi Y, Gong T (2013) Customer value co-creation behavior: scale development and validation. Journal of Business Research 66 (9): 1279-1284. https://doi.org/10.1016/j.jbusres.2012.02.026

Yllmaz Y, Bititci US (2006) Performance measurement in tourism: a value chain model. International Journal of Contemporary Hospitality Management 18 (4): 341-349. https://doi.org/10.1108/09596110610665348

Zhang X, Song H, Huang GQ (2009) Tourism supply chain management: a new research agenda. Journal of Tourism Management 30 (3): 345-358.

https://doi.org/10.1016/j.tourman.2008.12.010 